\title{
DETROIT'S URBAN REGIME: COMPOSITION AND CONSEQUENCE
}

\section{Leda McIntyre Hall}

Indiana University South Bend

Melvin F. Hall

Indiana University South Bend

Mid-American Review of Sociology, 1993, Vol XVII, No. 2: 19-37

This article examines the urban regime in Detroit, Michigan, specifically examining how the regime makes decisions about redevelopment and major capital projects. Detroit's urban regime, which emerged from the urban unrest of the 1960s, mobilizes resources, promotes cooperation, and manages conflicts between public and private interests to facilitate and justify redevelopment. Although political decision makers are represented in the regime, we argue that the business community's influence is pervasive, visible. and overwhelming. The participants in Detroit's regime are more adversarial and disrespectful of local political entities than regimes previously studied. Regimes may warp democratic processes to accommodate business interests because the financial decisions of economic institutions reverberate throughout the local political economy.

Since the publication of Peterson's City Limits, urbanists have debated his contention that cities are constrained not only by the necessity of economic competition but by the limits of resources primarily provided by their land area. Because of limited policy options and limited economic resources, Peterson (1981) argues that a city acts as a unitary interest, claiming to act for the city as a whole, when approaching land use decisions.

In the development of regime theory Stone $\left(1989 ; 1987 a_{;}\right.$. 1987b) counters Peterson's conclusion and argues convincingly that cities cannot and do not function as unitary interests when approaching land use decisions. Rather than suggesting a unitary ideological front, Stone argues that land use decisions pervade urban political conflict. Stone's definition of a regime identifies informal arrangements between city hall and the downtown business elite. An urban regime is defined as "the informal arrangements by which public bodies and private interests function together in order to be able to make and carry out governing decisions" (Stone, 1989:6). This informal partnership and the way it operates constitute the city's regime and enable public and private interests to manage conflicts, mobilize resources and promote cooperation (Stone, 1989:1). Recent research (Clarke and Gaile, 1992) suggests that these informal arrangements are actually a reflection of a shift in policy orientation in which 
market feasibility supersedes social criteria, downtown becomes the locus for redevelopment, and the city's role as a redeveloper is redefined. Such an orientation is evident in Detroit, the focus of this study.

The historical literature on community power developed from the debate between elitists (Mills, 1956; Hunter, 1959; Banfield, 1961) and pluralists (Truman, 1951; Dahl, 1961). Both arguments focus primarily on social and ideological control rather than the systemic and hegemonic perspectives offered by regime theory. That the business community in Detroit, Atlanta, or any other city influences city politics is not a remarkable observation. However, this study of Detroit's regime explicates and highlights regime theory by illustrating the informal, pervasive, and evolving impact of the business community. The informal relationships are not neutral; they are probusiness. Many demands are made of city officials by a variety of groups and individuals but few groups maintain consistent influence. This fragmentation provides fertile ground for a regime. "Community power," Stone concludes, "accrues to those with a capacity to act in what is an otherwise diffuse system of authority" (1989:230). The Detroit case illustrates how this capacity to act is orchestrated.

Analysis of structural factors offers additional insights into how land use decisions are made, Elkin (1987a) stresses the importance of understanding the composition of the urban regime, the structural factors that define the powers of cities and how cities relate to holders of economic assets. Like others Elkin divides labor between those who privately control capital or assets and city authorities. The organization of the regime, marked by this division of labor, is influenced by internal prerogatives and organization. The larger urban, state, and national and international political and economic environment also have an impact on the regime. 1

In his claim that the political ruling class does not control the state, Block (1977) argues that the state rationalizes capitalism. Those who manage the state apparatus depend on healthy economic activity to maintain support for the regime and will attempt to facilitate and encourage private investment in order to maintain or increase economic activity. Policies such as property tax abatements, subsidized interest rates and economic development corporations are in the general interest of capital and the political interest of the regime.

Debates on constraints, arguments about the political nature of the urban scene, and attempts to explain the configuration of decision making groups or regimes frame much of the current discussion of urban political economies. Logan and Molotch's (1987) theory of the city as a growth machine is particularly interesting when applied to Detroit, but that discussion is separate from our analysis of the regime (see Hall and McIntyre Hall, 1994). In the

1. A helpful, but by no means comprehensive list of research on urban decisionmaking and urban regimes includes Stone, 1989; Darden, Hill, Thomas, and Thomas, 1987; Elkin, 1987b; Stone and Sanders, 1987; Stone, 1987a; and Jones and Bachelor, 1986. primary growth machine literature, Logan and Molotch assign a use value and an exchange value to any given piece of land. Use values reflect residential concerns while the exchange value stems from rent or income generated from the property. The value of land is less in distressed cities for either use or exchange. but keeping the land-based economic elites and their resources on city ground is critically important to local governments. The regime is comprised of competing actors who want land use and capital investment to intensify.

We disagree with Peterson's assessment of the city as a unified interest. The goal of economic growth may be shared by regime members but the path to growth is acrimonious and littered with the self-centered demands of economic elites. Stone defends Atlanta's regime as one created by purposive choices made before World War II in which the white business elite and elements of the black middle class began to shape arrangements that were mutually beneficial. Although the influence of the auto industry pervaded Detroit by the 1920s, the current governing coalition emerged from the urban unrest of the sixties. The Detroit regime is much more adversarial and much more short-sighted than Atlanta's regime. Elkin argues that urban governments should be public-spirited and structured to include strong neighborhood associations with significant power, citywide referenda, and city legislatures with significant powers (1987a:171). We find a regime making decisions in Detroit while basically ignoring neighborhoods and co-opting an impotent city council. There is little of the public spirit found in either Atlanta or Elkin's model. Our contribution to the regime literature is to illumine a regime which is contentious and selfcentered while pervading land use decisions in Detroit.

A study of Detroit's regime offers an opportunity to apply regime theory to a city that is significantly different from Dallas (Elkin, 1987b) and Atlanta (Stone, 1989). As Elkin finds in Dallas and Stone finds in Atlanta, we find evidence in Detroit that political debate can occur and the business community's influence is not subtle. ${ }^{2}$ Detroit is older and more populous, a blue-collar, union town where the auto industry has been the dominant economic force for most of this century. Atlanta, a city with less than half the population of Detroit, has enjoyed relative economic health and benefitted from a diverse econemy: In contrast, Detroit's fortunes have been clearly tied to fluetuations in the auto industry for decades. The collapse of the domestic auto industry contributes significantly to Detroit's current malaise. Dallas, a relatively new' city with nearly the same population as Detroit, has been influenced by the boom-bust cycle in domestic oil prices and the savings and loan industry. However, diversification and the federal bailout of failed thrifts has shielded it

2. See Stone (1989) for a clear picture of the evolution of Atlanta's regime. Elkin (1987b) analyzes the regime in Dallas; and his seminal work (1987a) on cities and regimes was most illuminating to our work on Detroit. Eisinger (1980) offers a clear comparison of the emergence of black political power in Detroit and Atlanta. 
from the vulnerability inherent in Detroit's dependence on the auto industry (Fasenfest, 1986; Jones and Bachelor, 1986). Dallas is the only one of the three cities whose population grew between 1980 and 1990 and is projected to continue growth into the next decade. ${ }^{3}$

Our purpose here is to examine two decisions heavily influenced by Detroit's urban regime. The first was a decision to clear a site so that General Motors would build an assembly plant in the city, the Central Industrial Park Project (CIPP). The other decision was to facilitate a neighborhood redevelopment project around the General Motors (GM) world headquarters complex, the New Center Area. We will examine the regime by discussing what the political and economic actors bring to the bargaining table, and evaluating the regime's role in redevelopment decisions in Detroit.

\section{THE CASE OF DETROIT}

Business confidence - the traditional capitalist's evaluation of the general political and economic climate - is particularly low in Detroit. In such an environment, it is logical for the regime to marshall whatever resources are available to improve business confidence. Because the regime can fall if economic activity decreases the political leaders purport to be trapped between Scylla and Charybdis: politicians must make economic development decisions which benefit corporate and commercial interests or fall. Lindblom (1988) argues that political decision makers may warp democracy to devise policy which accommodates business interests because of the potential impact economic institutions have on the market (local and wider), on governments, and even on the public (1988). In even narrower parameters, the Detroit political administration must respond to demands from the auto industry as a single investment decision. If $\mathrm{GM}$ or Chrysler threaten to move a facility from Detroit they can paralyze or weaken the political position of the mayor and his administration.

Fasenfest (1986) posits that antecedent processes may structurally favor one set of possible outcomes over another set. He argues that Emmett Moten, direstor of Detreit's Community and Economic Development Department (CEDD), stacked the deck for General Motors, limiting the city's options to a range of outcomes which benefitted $\mathrm{GM}$ as a corporate entity. 4

From a less marxist but still structural viewpoint, Jones and Bachelor (1986) propose the term sectarchy to describe power in Detroit. They contend that political power is based in the sectoral organization of the political economy. Various business, labor, and political leaders occupy key

3. The 1980 population of Detroit was 1.2 million and 1.03 million in 1990. Atlanta's census found 425,022 residents in 1980 and 394,017 in 1990. Dallas had 904,078 residents in 1980 and just over one million in 1990.

4. See Ewen, 1978, for an historical view of the power structure in Detroit. organizational positions in forums where major decisions are made. While particular members may change, the key positions in the regime are fairly constant over time. Urban decisions involving allocational policies within the governmental sector tend toward pluralistic decision making. It is when sectors meet to decide on costly redevelopment projects, that more elitist bargaining takes place. Bargaining proceeds, but often in the shadow of an implied threat from economic elites that they will simply withdraw capital from the city if their needs are not addressed or if their demands are not met.

\section{THE COMPOSITION OF THE CURRENT REGIME IN DETROIT}

The influence of the downtown business elite on political decisions is crucial to understanding Detroit's regime. The current regime evolved through the formation of three organizations, all of which involved public officials but remained under private control. Following the urban riots in 1967, a pioneering coalition of African Americans, labor, government, and business leaders called New Detroit was assembled to study neighborhood needs and facilitate publicprivate partnerships to fund development in black neighborhoods and involving minority businesses. While New Detroit has evolved into an advocacy and lobbying group, it is significant in the emergence of Detroit's regime for two reasons. First, the leadership of New Detroit has been African American. and the organization provides a podium for those who may not be included in the regime. Second, in a city that is now $76 \%$ black, New Detroit visibly focuses on African-American neighborhoods and minority-owned businesses.

A second and more business oriented coalition called Detroit Renaissance emerged by 1971. Auto industry leaders joined financiers and developers to represent the interests of the elite business community in development, particularly in the downtown area. The group concluded that a major development project along Detroit's riverfront was needed to change the image of downtown and provide a catalyst for the renewal of the central city. Construction began in 1973 on the Renaissance Center, a hotel, office, and commercial project financed by an elaborate partnership assembled by Henry Ford II. Ford Motor Company leased several floors and moved hundreds of employees into RenCen offices. However, cost overruns, Ford employee resistance to working in Detroit, and high rates of commercial vacancy led to bankruptcy for the project by 1982 .

Although Detroit Renaissance continues to focus on downtown development, the third and most significant component of the regime was formed in 1978. Enabled by Michigan's Economic Development Corporation Act (Public Act 1974, 338), Detroit established an Economic Development Corporation (EDC). EDCs are charged with sponsoring programs to alleviate and prevent unemployment and to encourage industrial and commercial development. Powers of EDCs include acquiring land for project sites. making loans or issuing bonds to finance projects, constructing facilities and selling or leasing the project to a commercial or industrial interest. The act transfers public policy making responsibilities to the EDC, primarily a private sector 
enterprise, and formalizes its place in the regime (Squires, 1989; Levine, 1989). The membership of Detroit's EDC is comprised of at least nine city officials and business people. In 1981, the members of the Board of Directors, which the mayor chairs, were an attorney from a major downtown law firm, GM's real estate property manager, the president of Detroit Renaissance, two commercial executives, a bank vice-president, a city councilmember, and the director of the city's Community and Economic Development Department (Bruhn, 1991). Labor, neighborhoods, and small businesses were not represented on the board. While the faces have changed, the source of board members remains basically unchanged through 1991.

The Detroit Economic Growth Corporation (DEGC), the industrial redevelopment specialists in the EDC, wields tremendous influence over the selection of the city's development projects. ${ }^{5}$ Currently, the executive committee of the Detroit Economic Growth Corporation has eighteen members: sixteen corporate executives, one officer of the statewide AFL-CIO, and Mayor Coleman Young (DEGC, 1991). During the years the DEGC was headed by the Chair of the Board of GM, the group sponsored the two projects discussed in this article, the Central Industrial Park Project and the New Center Area. ${ }^{6}$

Some observers suggest that a glance at Detroit's riverfront skyline reveals who really wields power over development and illumines the inherently inferior position of public officials in economic redevelopment. One sees Riverfront West (a federally subsidized high rise, high rent apartment complex built and owned by (wo major developers) [Detroit Mayor] Coleman Young's Joe Louis Arena and Cobo Hall, Henry Ford's Renaissance Center, Stroh's River Place (an apartment and entertainment project) and ANR's Harborside (a chic commercial and residential development owned by ANR, a natural gas pipeline and exploration holding company) (Squires, 1989; Darden, et. al., 1987). City Councilmember Mel Ravitz observes, "There is [a] tale of two cities in Detroit, one city along the river being built; the other consisting of the neighborhoods where a million people live, being slowly eroded, neglected, destroyed" (Ravitz, 1988:21). Neighborhood decline persisted through periods of activist urban policy such as the Model Cities Program, exacerbated by white flight, the "malling" of the area, and the exodus of much of the tax base.

\section{THE DOWNTURN IN DETROIT}

The term "economic downturn" takes on a whole new meaning when used in Detroit. Despite infusions of federal and state money, the economic health of Detroit worsens. Population decline that began in the fifties accelerated in the late sixties and continues; in thirty years, the city lost thirty-five percent of its

5. For an additional perspective on Detroit, see June Manning Thomas, (1989).

6. For a perspective critical of the Central Industrial Park Project, see Wylie, (1989). residents. Between 1950 and 1980, the number of Detroiters employed in manufacturing jobs dropped sixty-eight percent. Economic reports show that metropolitan industrial investment targeted to Detroit fell from forty-four percent in 1958 to twenty-two percent in 1977. Nearly fifty percent of Detroit's manufacturing jobs disappeared. Commercial disinvestment during the same years was catastrophic, culminating with the 1983 closing of the downtown Hudson's department store. By 1980, unemployment in the city was fifteen percent (more than fifty percent for young black men), violent crime was on the increase, and major industrial employers were posting losses and laying off employees. One-third of the city's adults had no earned income, sixty percent received some form of public assistance, capital was fleeing the city. and public services were dramatically curtailed.

In 1991, the overall unemployment rate had increased slightly from 1980 estimates. While employment opportunities exist in suburban areas many Detroiters lack transportation. The city government had a $\$ 58$ billion deficit in the 1991 budget year which had to be erased by further cuts in city services and expenditures. More than fifty percent of students who enter ninth grade in the Detroit public schools never complete high school.

While the city imploded, the opposite occurred in Detroit's suburbs. Detroit's suburbs are functionally autonomous and politically isolated from the city. This isolation can be attributed to several circumstances ranging from the white flight which began in the early sixties to the 1967 urban riots to Mayor Coleman Young's overt hostility toward suburban communities. Residents and businesses who could do so physically abandoned Detroit although many continued to rely on the city for manufacturing jobs and customers. Shopping outlets also moved out of the city; in 1958, there were ten major shopping areas in the city and ten in the suburbs. By 1.985, one major shopping mall remained in Detroit while nineteen suburban shopping areas controlled ninety-two percent of the area's retail trade (Darden, et. al., 1987).

Since the inception of the automobile industry, prosperity in Detroit has been tied to that industry. The auto industry had been sliding into difficulty in the seventies but experienced a precipitous decline in 1980. A global reorganization strategy, headlined by massive work force reduetions. sent major shock waves through the auto industry (Smith and Feagin, 1987). In 1978, there were 735,000 hourly workers, a number reduced to 565,000 by 1984 ; tens of thousands of workers in supplier industries also lost their jobs. With more than half of Detroit's workers employed in auto or auto related industries, the impact was immediate and devastating. General Motors, Ford Motor Company, and Chrysler Corporation reported plummeting profits: Ford and Chrysler experienced several quarters with after-tax losses and GM its first annual net loss since 1921. GM announced that it planned to close two assembly plants in Detroit, plants where 15,000 auto workers assembled slow-selling luxury cars. Four additional Detroit area plants were slated for closing in 1982 and GM announced intentions to build four facilities in Mexico. 
In 1973, Coleman Young emerged through the United Auto Workers union and was elected mayor. Until the 1989 election, which he won with his narrowest margin of victory ever, Young's electoral strength was overwhelming, enabling him to dominate the City Council. Only recently has the Council maintained the needed votes to override any of Young's legislative initiatives and even then disagreement has been slight. How has Young maintained such electoral strength? Is he, as some critics claim, a marionette mayor whose strings are pulled by the business community or is he an assertive leader who parlays private investment into the common good? Young occupies a key position in the regime as mayor of the city. At the regime level he provides administrative and political clearance for privately sponsored economic development. Concurrently, he is the political leader of a city in which powerful African American groups support him because he has been their advocate for two decades. Many neighborhoods support him because of his political savvy in the dispensation of patronage and neighborhood improvement funds and because of the enduring support from most of the African American clergy.

Detroit has a strong mayor-weak council form of government bolstered in the last two decades by Young's invincibility at the polls. Until the last two mayoral elections Young ran with only token opposition and even with more serious opponents, Young received more than fifty-five percent of the vote. There are informal slates for City Council elections endorsed by the mayor and made known to neighborhood leaders, the African-American clergy, and local party officials (and actually secret from no one). Coveted UAW endorsements for City Council elections are overtly influenced by Young, and "being on the slate" or receiving the UAW's endorsement makes one more electable - but beholden to the mayor. Throughout the last decade, Young has maintained a million dollar "war chest" to fund his re-election campaigns and to assist the slate. Council membership has been mostly minority, Democratic, and fiercely loyal to Coleman Young. In addition to the support he receives from City Council, Young has surrounded himself with articulate and loyal administrators. He appoints the director and top assistants in each city department, and they serve at his pleasure.

During the Carter administration Young and his Community and Economic $\rightarrow$ Developinent- Department; - bolstered by the Detroit Economic Growth Corporation, secured millions of federal dollars for development primarily through the Community Development Block Grant (CDBG) and the Urban Development Action Grant (UDAG) program. Between FY75, when the CDBG allocations began and FY91, Detroit received nearly $\$ 850$ million, earmarked by Congress to benefit low and moderate income areas. In spite of this federal mandate that CDBG funds should benefit low and moderate income people, all of the riverfront developments listed above (except the RenCen) and the two GM projects discussed were funded in part with CDBG funds. Mayor Young and the City Council have offered with impunity every available incentive to businesses and corporations willing to stay or expand in Detroit. Until his untimely death in 1988, Councilmember Ken Cockrel, a self-avowed Marxist, made vociferous
Detroit's Urban Regime

arguments that some quid pro quo (for instance, a guaranteed number of jobs, commitment to stay $x$ years, accept less than the maximum tax abatement) between the City and businesses was appropriate, but his position was hardly given a serious hearing. Councilmember Mel Ravitz proposed an ordinance in 1991 that would have mandated contractual commitments between businesses and the city when an abatement is granted, but the Council defeated the measure (Ravitz, 1992).

Legislation allowing Michigan cities to exempt industrial and commercial facilities from real and personal property taxes for up to twelve years was passed in 1974 (Public Act 198). Recommendations for tax abatements are presented to City Council by the Community and Economic Development Department in conjunction with a review and approval by the Detroit Economic Growth Corporation. The Detroit City Council passed the first abatement resolution in 1975 and followed it with 326 additional project abatements by 1986. Each resolution was approved at the maximum of a fifty percent abatement of real and property taxes for the full twelve years allowed. Until very recently, city authorities gave economic benefits and bonuses to businesses and only asked that they stay in town for the time being. No conditions have ever been placed on a company which accepted land, a property tax abatement, a low interest loan, or a grant from the City (Ravitz, 1988, 1992; Bruhn, 1991). ${ }^{7}$

In addition to local incentives, the CEDD sponsored Urban Development Action Grants, a federally funded program (now nearly defunct) designed to facilitate development by providing public matching funds for private expenditures. Detroit received forty-one UDAGs between 1981 and 1987. totaling $\$ 139$ million; the concomitant private development approaches $\$ 2.8$ billion.

Detroit is mired in an "edifice complex" and a corporate oriented approach to development. Neither posture has led to an improvement in urban poverty levels or stopped neighborhood decline. Levine suggests that public-private partnerships typically involve three components, all of which are present in Detroit: financial inducements, quasi-public redevelopment corporations, and an entrepreneurial mayor (Shearer, 1989; Levine, 1989). Mayor Young overtly courts the business community; encourages and reiies on the DEGC, and facilitates the packaging of redevelopment options for the private sector.

Many economic resources that come to or are solicited by Detroit's development administrators are earmarked for downtown redevelopment projects. Even the Community Development Block Grant (CDBG), designed to improve housing and develop neighborhoods, has been part of Young's package. Between

7. In early 1992, the Detroit City Council, for the first time, rescinded a tax abatement. The Pepsi-Cola Company was granted the full abatement and promised to provide 800 new jobs, most earmarked for city residents. When the finished project produced barely 200 new jobs, Council acted. Pepsi's appeal is in court. 
1975 and 1982, fifty-two percent of the block grant allocations went to projects in the central business district, the riverfront, and the Woodward Corridor (which includes the New Center Area) (Thomas, 1989:189). CDBG funds since 1982 are either directly allocated to or held as collateral for the Central Industrial Park Project.

It is not always true that urban political leaders so clearly curry the favor of the business elites. There are several examples from Boston and Chicago where avowed progressive mayoral candidates attempted to reshape public-private partnerships more equitably. In these cities, downtown development is linked to building low-income housing, local officials pursue financial rewards to offset public risks, and neighborhoods outside the central business district benefit from redevelopment. Officials in these cities facilitate public-private partnerships, and they have diligently attempted to equalize the partners (Stone, 1987b).

\section{THE CENTRAL INDUSTRIAL PARK PROJECT}

The economic existence of the city of Detroit is so precarious that the loss of any manufacturing facility sends cataclysmic shudders through both administrative and legislative hallways. When GM offered Detroit the chance to prepare a site for a new assembly plant the offer was significant for two reasons. GM claimed that the new facility would employ 6,000 United Auto Workers when it opened. Second, securing the project for Detroit was symbolically important. The new plant would mean investment by GM in Detroit: not just jobs but an economic linchpin for the city. With an air of triumph that Mayor Coleman Young joined GM chair Thomas Murphy in June of 1980 to announce that a new $\$ 500$ million Cadillac plant would be built in Detroit. The proposed site included a vacant Dodge assembly plant and the northern third of the Poletown neighborhood. "There is," said Mayor Young, "a state of emergency within the city and bold, far-reaching and innovative initiatives, beginning with the city's Central Industrial Park Project (CIPP), must be undertaken immediately to deal with the foundations of this crisis" (Wylie, 1989:48).

This bold initiative required that the city, using an expedited eminent domain law would have to take title to and clear 1,400 homes, 144 businesses, and sixteen churches in Poletown. The city would have to pay property owners a fair market rate plus relocation costs, clear the land, and meet environmental guidelines for clearing toxic wastes. GM also requested and received a twelveyear, fifty percent property tax abatement on the site which represents $\$ 60$ million in lost revenue to the city. The original estimated public contribution was $\$ 200$ million for land acquisition, relocation, demolition, and site improvement. ${ }^{8}$ What pressures were brought to bear on government decision

8. A substantial portion of this amount was taken from Community Development Block Grant funds both as outright expenditures and loans against future CDBG entitlements. Other revenue sources included UDAGs, makers and the public to commit such sums? Symbolically, General Motors contended that the government's taxation and trade policies were partly to blame for the demise of the auto industry, therefore government should facilitate the CIPP. GM also exerted control over site determination, and corporate planners rejected outright eight of nine alternative sites proposed by CEDD. several of which involved much less displacement while claiming they were being good neighbors by providing needed jobs (Cunningham, 1989; Wylie, 1989). Finally, GM officials clearly stated that if Detroit chose not to meet their needs. the company would simply build the plant somewhere else (Bruhn, 1991; Wylie, 1989; Jones and Bachelor, 1986; Corsetti, et.al., 1983).

No doubt, Peterson would hear Mayor Young's assessment that ..."this [Central Industrial Park] project is the best thing to happen to the City of Detroit in a long time..." (Corsetti, et. al., 1983) and find evidence of the city as a unitary interest. The suggestion could also be made that the decision to fund the CIPP was consensual and closed to the public until technical and political feasibility was assured. Coleman Young's reputation as a fighter for Detroit was, at least in some circles, enhanced.

In response to a suit brought by the Poletown Neighborhood Council, the majority opinion indicated that five of the seven justices were convinced that the city provided evidence of economic distress and the lack of other adequate sites for the Poletown plant. The Court went on to say, "In this case the benefit to be received by the municipality...is sufficient to satisfy this court. The benefit to a private interest is merely incidental (Poletown Neighborhood Council v. Ciny of Detroit). Although two dissenting justices vehemently contended that public funds were being used for a private project, the Court acted in record time, allowing the city to meet GM's deadline and proceed with the CIPP.

However, Stone argues that, even with a policy such as funding the CIPP, people may differ in the opinions about the impact of the policy. What one sees depends on where one stands: with city officials, with the Poletow'n Neighborhood Council, with General Motors. A regime decision to spend more than $\$ 300$ million on the CIPP benefits GM, but the decision siphoned off

Êconomic Development Administration grants, state loans and loan guarantees, and Michigan Department of Transportation grants. Trying to unearth the final public cost of the CIP Project is an exercise in futility. Because of outstanding loans and unsettled lawsuits the exact final cost is not yet available and, due to budgeting and accounting gymnastics uithin various city departments, the current cost of the CIP Project is undiscernible. This according to Ravitz (1992), Bruhn (1991), and Lowe (1991). A fascinating research project--if it would be allowed--would be to trace the threads of local, state and federal money through the project web to arrive at the public expenditure. One might conclude from such a convoluted financial picture that "total project cost" is not a number the Young administration wants published. 
neighborhood redevelopment funds for at least a decade because of loan and bond obligations guaranteed by and payable from CDBG funds.

At some level, the city as a whole benefitted even if only symbolically, but hundreds of Poletown residents lost their homes. The city paid for relocation, but family and neighborhood traditions were forfeited. The new Cadillac plant eventually provided some jobs, but thousands of other auto workers in the city subsequently lost their jobs as part of GM's reindustrialization program. There is a three percent city income tax, halved for those who work in the city and live elsewhere, but there was an eventual net loss in income tax revenues because of subsequent plant closings. GM pays only half of the property tax assessment for twelve years and property tax revenue was lost on demolished homes in Poletown and declined on those area properties remaining (Ravitz, 1992; Bruhn, 1991). In hearings and public meetings GM officials and Emmett Moten of the Community and Economic Development Department frequently alluded to "6,000 jobs" at the CIPP. CEDD's analysis suggested that the CIPP made sound economic sense if the new plan operated with two full shifts and maintained backfill operations at the nearby Fleetwood and Clark Assembly plants. ${ }^{9}$ Up to 20,000 spin-off jobs were projected.

The only promised benefit of the new plant was jobs. According to GM's public relations office, the plant ran two shifts until early 1987 when layoffs eventually totalling 2,000 workers began. In early 1992, 2,800 auto workers ran one shift; a second shift, eventually recalling 1,000-1,500 workers will be phased in by the summer of 1993. All of the employees at the CIPP are transfers from the Fleetwood and Clark Assembly plants (the latter of which closed before the Poletown plant began production and idled 15,000 workers) and a small limo operation. The minimum seniority held by these UAW employees is fifteen years with GM. About forty percent of the CIP plant employees live in the city of Detroit (Sylvester, 1992). Councilmember Ravitz calculates the total project cost between $\$ 250$ and $\$ 300$ million. The number of jobs at the Poletown plant has never reached the 6,000 jobs promised. With 4,800 jobs 1,920 held by Detroit residents - the cost per resident job is $\$ 156,250$ (Ravitz, 1988). Even if "economic conditions" are somehow used to justify this project, the beneñiciariês of thể CIPP'are not Detroit's poor or Detroit's neighbortioods. Some observers take a long and optimistic gaze into the future and contend that the Poletown plant will emerge as one of the future flagships of GM's downsizing effort. If so, Detroit could yet reap real benefits from the project.

9. See David Fasenfest (1986) for a thorough discussion of the shortcomings of using benefit and cost analysis as the sole determinant of economic development policy.

\section{THE NEW CENTER AREA}

Detroit's New Center area, the second project considered in this study, is home to the corporate headquarters of the General Motors Corporation. 10 Despite a general decline in the area since the 1960s, GM made a commitment to stay and invested $\$ 35$ million in building and facilities renovation during the early seventies. Beginning in 1977, GM embarked on a $\$ 1.25$ million landscape beautification project including the construction of two mini-parks. GM then looked to the residential neighborhood north of its corporate facilities and sought ways to revitalize the area. A consulting firm recommended a comprehensive community development program. Features included a major private thrust into housing rehabilitation, the creation of a framework in which area businesses and institutions, the lending community, government, and citizen groups could participate, and firm joint public/private commitments. General Motors wanted to improve the neighborhood, spur redevelopment in Detroit and create a model for redevelopment (Gregory, 1989).

GM was not being entirely altruistic as the cost of revitalizing the area is minute compared to the cost of relocating the corporate headquarters operation. Although the GM investment totals nearly $\$ 20$ million, the city contributed $\$ 4.9$ million to New Center Area residential redevelopment in the early eighties via Urban Development Action Grants and a portion of the Community Development Block Grant. State housing funds were also made available to subsidize construction and rental of low income family housing and the apartments for senior citizens. Public and private forces were needed to address a plethora of problems in the area, including the effects of redlining. excessive traffic, poor planning, uncoordinated zoning changes, governmental neglect, racial prejudice, absentee slum lords, drug addiction, and a concentration of the poor, the elderly, and the mentally ill.

With images of Poletown still fresh, city officials hoped to circumvent any opposition to the New Center project related to displacing area residents. One of GM's consultants (Gladstone, 1988) warned that displacement can become an explosive community issue, jeopardizing program success and tarnishing the image of the developers. On its UDAG application, the city's Community and Economic Development Department (CEDD) claimed there would be no displacement of residents by the city, implicitly blaming GM (Cunningham, 1989); and GM's Development Corporation contended they were merely rehabilitating vacant structures and building new structures on city-owned vacant land, implicitly laying displacement at the city's feet. City Council's City Planning Commission accused the GM proposal of displacing an entire community of people (Brownell, 1978) and GM's own project report

10. The General Motors headquarters building is not located downtown, but in the New Center Area, approximately three miles from the Detroit's downtown and riverfront area. 
acknowledges the displacement of nearly three hundred tenants. Community acknowledges the displacement of nearly th CEDD demanding redress for the groups joined in an outcry against GM and CEDD demanding redress for the displacement, and the protests proved advantageous to at least some of those displaced. To settle the issue - not to stop displacement, but to alleviate the resistance - CEDD added $\$ 800,000$ to the UDAG to fund a tenant relocation program. The development corporation also added apartment housing for senior pritizens and low-income family housing to plans for the area, giving this redevelopment an income mix seldom occurring in such projects. These additional expenditures were not made at GM's insistence, but because the city addressed civic concerns on behalf or instead of General Motors.

The New Center Area is a twenty-two block redevelopment just north of GM's world headquarters building. New Center Commons, the residential component, includes forty-eight single family housing units, forty-seven component, includes forty-eight single family subsidized housing, and two condominium units, fifty-four units of family subsidized housing, and two
hundred apartments for senior citizens. The latter two components are a clear divergence from other urban redevelopment projects which are, typically, the exclusive province of at least upper middle income households. Concurrent redevelopment has also occurred in the form of office, retail, parking and hotel development. Argonaut Realty targeted white collar employees at GM, the Henry Ford Medical Center, Wayne State University, and Unisys Corporation with its first sales blitz; to their disappointment, and implicitly to GM's, few auto executives relocated to New Center Commons.

\section{Summary Observations}

Decisions about economic redevelopment in Detroit are made by an urban ime comprised of the mayor and persons holding key organizational positions in the elite business community. A list of regime members parallels the membership list of the Economic Development Corporation and the Detroit Economic Growth Corporation along with Coleman Young and the director of the Community and Economic Development Department.

The Economic Development Corporation and the Detroit Economic Growth Corporation have standing in the political process. Functionally, the commercial and industrial interests represented have a legitimate role in the regime. It is, however, unlikely that redevelopment decisions in Detroit would be different if there were not an EDC or the DEGC. Although decisions might be less expeditiously made, bargaining about planning and funding large capital projects would engage similar key business leaders and the mayor. The state in general is dependent on the investment accumulation process and Detroit is certainly no exception.

Development policy is inextricably connected with issues about who benefits and who bears the cost. The decision to fund the Central Industrial Park Project was primarily shaped by GM, Mayor Young, and the Detroit Economic Growth Corporation. Minor roles were allowed the City Council, the Poletown Neighborhood Council, the United Auto Workers, the Michigan Legislature, and other activists. Similarly, GM, the DEGC, and the city made the only decisions that mattered concerning redevelopment in the New Center Area. The burden of cost was assigned according to the relative bargaining position of each actor, and some actors received few benefits. Fasenfest says it most succinctly, "The people of the city of Detroit assumed all the expenses and took all the risks" (Fasenfest, 1986:114).

While the Detroit Economic Growth Corporation laid aside its downtown emphasis, the group was instrumental in coordinating funds for the New Center Commons development. GM relied on an in-house fiduciary agent, Argonaut Realty, to purchase options on properties and eventually offer renovated houses for sale on the real estate market (Spreitzer-Berent, 1989). The public expenditures were primarily for relocation assistance, street, and lighting improvements. As with the CIP Project the policy impacts of the New Center redevelopments varied according to one's perspective. In purely physical terms, the GM developments were progressive. The area is cleaner, the city reaps higher property tax revenues, and the image of slum neighborhoods has disappeared. However, the former residents, many of whom were low income single adults and African Americans, lost their homes. GM's world headquarters facility remains, but few GM employees moved into New Center Commons housing. Key factors contributing to the success of this project were support from the Young administration, the availability of financing, enough renovated housing units to generate market momentum, and well planned and executed marketing strategies. Many political and economic interests are manifest.

Economic actors bring tremendous strength to the bargaining table. They have resources, jobs - real and promised, and mobile capital. Detroit's political actors bring a city full of needs: jobs, housing, social services, simple necessities. They also have economic incentives: tax abatements, special tax districts, land, CDBG funds, and the ability to leverage and package limited state and federal funds. What Detroit wants is real or at least symbolic redevelopment: someone building something, fifty or a hundred new jobs. If political actors do not facilitate economic development, economic actors simply leave town.

Much as the image of a growth machine seems forced in Detroit, the publicspiritedness of the Atlanta regime does not fit either. There is not an hónest sense of working for the common good, but the image of mayor who mouths these words while participating in regime decisions. Detroit's government more closely resembles Elkin's assessment of Dallas' government: the business elite maintain a political system "in which those who hold elected and appointed office do not have to be told what to do" (Elkin, 1987b:30).

From a socio-political standpoint, in a city as desperately poor as Detroit, it seems unconscionable that the mayor aggressively courts corporate interests and investment with public funds. Destroying Poletown for even 4,800 GM jobs and assisting in the gentrification of the New Center Area seem incongruous with Detroit's needs for basic shelter and employment for many residents. In his defense, the mayor is neither an independent nor an isolated leader. As an elected political leader, Young dispenses benefits to community organizations and 
neighborhoods. From a regime view, Young fulfills the responsibility of his political position - his power role in the regime - by compressing public resources into economic redevelopment projects consequently directly benefitting members of the regime who hold economic power. Detroit is a city with few options, so it may be unduly harsh to judge Mayor Young by the same political and economic standards as one might use in Dallas or Phoenix or San Diego. He does what he does to generate jobs in desperate times. He pursues economic development while concurrently making both the neighborhoods and developers beholden to him. However insignificant two thousand jobs and a few dozen homes are in the big picture, the Central Industrial Park Project and the New Center Area redevclopments benefit GM and improve, however slightly, the business climate in Detroit.

Detroit is also the center of one of America's most segregated regions. If Detroit and its suburbs are to succeed and compete globally, regional economic initiatives may be necessary. There are two regional groups which merit mention both because of their activities and because the Detroit regime no doubt responds to their suggestions. The Southeast Michigan Council of Governments has promulgated a Regional Development Initiative which is large and long term in scope. There is also a group called the Six Pack (comprised of Wayne, Oakland and Macomb Counties, the City of Detroit, the Michigan Departments of Commerce and Transportation). This informal group provides advice on regional planning and development policies.

Young's part in the regime may be as a minor player in a bigger game, and even the Detroit regime is subject to pressures which emerge and prevail far beyond the city limits. In the capitalist state, the political system and the economic system are inseparable and symbiotic, but economic interests are paramount. The regime's imprimatur on the Central Industrial Park and the New Center Area is different only in degree when compared to Kentucky's largess toward Toyota or Indiana's accommodation of Isuzu. Rule 1 of the capitalist bargain is that economic interests win. Rule 2 is that cities and states must somehow abide by Rule 1.

We conclude that Detroit and similarly distressed cities are indeed limited, perhaps even more than Peterson imagined. They are constrained by declining.. economic resources, land area, and the existence of contentious urban regimes which exist in a larger network of state, national, and international political and economic actors. In that context, demolition of a neighborhood or displacement of a few dozen residents pale when juxtaposed against international competition for economic resources, development, and jobs. City officials and their development options are limited by - even captives of - economic elites whose interests often lie far beyond the city's boundaries.

\section{REFERENCES}

Banfield, Edward C. 1961. Political Influence. New York: Free Press.

Block, Fred. 1977. "The Ruling Class Does Not Rule: Notes on the Marxis Theory of the State." Socialist Revolution 33:6-30.

Brownell, Donald C. 1978. "Honorable City Council, RE: UDAG Application for New Center Area Revitalization Project." Memo to the City Council of Detroit, Michigan, October 30, 1978.

Bruhn, Marsha. 1991. Director, City Council's City Plan Commission, Detroit City Council. Personal interviews November 6 and November 12. 1991.

Clarke, Susan E. and Gary L. Gaile. 1992. "The Next Wave: Postfederal Local Economic Development Strategies." Economic Development Quarterly 6:187-198.

Corsetti, George, Jeanie Wylie, Richard Wieske. 1983. "Poletown Lives!" Film released, March. Detroit: Information Factory.

Cunningham, Thomas. 1989. Detroit Community and Economic Development Department. Interview May 11, 1989.

Dahl, Robert A. 1961. Who Governs? New Haven: Yale University Press.

Darden, Joe T., Richard Child Hill, June Thomas, Richard Thomas. 1987. Detroit: Race and Uneven Development. Philadelphia: Temple University Press.

Detroit Economic Growth Corporation. 1991. "Board of Directors." Detroit: DEGC.

Economic Development Corporations Act. Act 338, P.A. 1974. M.C.L.A. 125.1601-1636.

Eisinger, Peter K. 1980. The Politics of Displacement: Racial and Ethnic Transition in Three American Cities. New York: Academic Press.

Elkin, Stephen L. 1987a. City and Regime in the American Republic. Chicago: University of Chicago Press.

1987b. "State and Market in City Politics: Or, The "Real Dallas." In The Politics of Urban Redevelopment, Stone and Sanders, editors. Lawrence: University Press of Kansas.

Ewen, Lynda Ann. 1978. Corporate Power and Urban Crisis in Detroit. Princeton: Princeton University Press.

Fasenfest, David. 1986. "Community Politics and Urban Redevelopment: Poletown, Detroit, and General Motors." Urban Affairs Quanterly' 21:101. 123.

Gladstone Associates. 1978. "Revitalization Strategy Recommendations: New Center Area." Consultant report prepared for General Motors Corporation. March, 1978.

Gregory, Robert F. 1989. "New Center Revitalization Program, Detroit, Michigan." Project Manager's Report, May 1, 1989.

Hall, Melvin F. and Leda McIntyre Hall. 1994. "A Growth Machine for Those Who Count." Critical Sociology 
Hunter, Floyd. 1959. Top Leadership U.S.A. Chapel Hill: University of North Carolina Press.

Jones, Bryan D. and Lynn Bachelor. 1986. The Sustaining Hand: Community Leadership and Corporate Power. Lawrence: University Press of Kansas.

Levine, Marc V. 1989. "The Politics of Partnership: Urban Redevelopment Since 1945." In Unequal Partnerships, edited by Gregory D. Squires. Brunswick: Rutgers University Press.

Lindblom, Charles E. 1988. Democracy and Market System. Oslo: Norwegian University Press.

Logan, John R. and Harvey L. Molotch. 1987. Urban Fortunes: The Political Economy of Place. Berkeley: University of California Press.

Lowe, John. 1991. Detroit Planning Department. Personal interviews November 6 and November 12, 1991.

Mills, C. Wright. 1956. The Power Elite. New York: Oxford University Press.

Peterson, Paul E. 1981. City Limits. Chicago: University of Chicago Press.

Plant Rehabilitation and Industrial Development Districts Act. Act No. 198, P.A. 1974. M.S.A 7.800, Sec. 1-21.

Poletown Neighborhood Council v. City of Detroit. 410 Mich 610, 304 N.W. 2nd 455 (1981).

Ravitz, Mel. 1992. Personal interview (March 31).

1988. "Community development: Salvation or Suicide?" Social Policy 19:17-21.

Shearer, Derek. 1989. "In Search of Equal Partnerships, Prospects for Progressive Urban Policy in the 1990s." In Unequal Partnerships, edited by Gregory D. Squires. New Brunswick: Rutgers University Press.

Smith, Michael P. and Joe R. Feagin, Editors. 1987. The Capitalist City. New York: Basil Blackwell, Inc.

Spreitzer-Berent, Barbara L. 1989. Argonaut Realty, General Motors Corporation, Detroit, Michigan. Interviews June 6, June 20, June 28, 1989.

Squires, Gregory D., Editor. 1989. Unequal Partnerships: The Political Economy of Urban Redevelopment in Postwar. America.. New Brunswick: Rutgers University Press.

Stone, Clarence. 1989. Regime Politics. Lawrence: University Press of Kansas.

1987a. "The Study of the Politics of Urban Development." In The Politics of Urban Development, Stone and Sanders, editors. Lawrence: University Press of Kansas.

1987b. "Summing Up: Urban Regimes, Development Policy, and Political Arrangements." In The Politics of Urban Development, Stone and Sanders, editors. Lawrence: University Press of Kansas.

Stone, Clarence and Heywood T. Sanders. 1987. The Politics of Urban Development. Lawrence: University Press of Kansas.
Sylvester, Ann Marie. 1992. Public Information Officer, General Motors Corporation. Personal interview (April 1).

Thomas, June Manning. 1989. "Detroit: The Centrifugal City." In Unequal Partnerships, edited by Gregory D. Squires. New Brunswick: Rutgers University Press.

Truman, David. 1951. The Govemmental Process. New York: A.A. Knopf.

United States Department of Commerce. Bureau of the Census. 1950, 1960, 1970, 1980, 1990. Census of the Population, Characteristics of the Population; Michigan. . 1972, 1977, 1988. County and City Data Book.

Wylie, Jeanie. 1989. Poletown: Community Betrayed. Urbana: University of Illinois Press. 